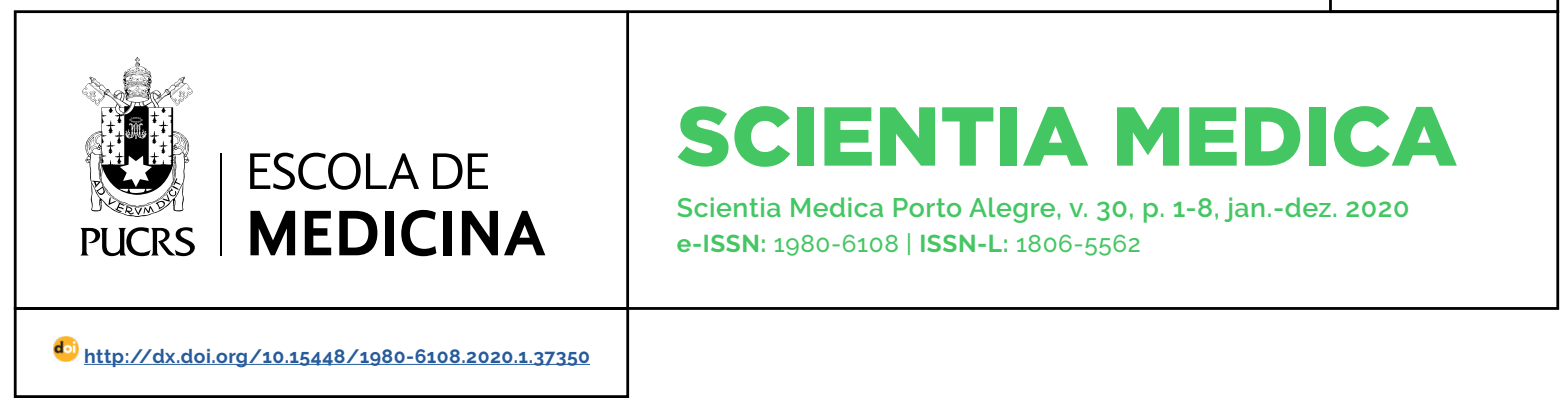

EDUCATION IN HEALTH SCIENCE

\title{
What does research on clinical reasoning have to say to clinical teachers?
}

\author{
O que a pesquisa sobre raciocinio clínico tem a dizer a preceptores e professores de \\ áreas clínicas?
}

\section{Silvia Mamede ${ }^{1}$}

orcid.org/0000-0003-1187-2392

s.mamede@erasmusmc.nl

Recebido em: 13 mar. 2020.

Aprovado em: 05 abr. 2020.

Publicado em: 19 jun. 2020.

\section{(c) (1)}

Artigo está licenciado sob forma de uma licença Creative Commons Atribuição 4.0 Internacional.
Abstract: Clinical reasoning is a crucial determinant of physicians' performance. It is key to arrive at a correct diagnosis, which substantially increases the chance of appropriate therapeutic decisions. Clinical teachers face the daily challenge of helping their students to develop clinical reasoning. To select appropriate teaching strategies, it may be useful to become acquainted with the results of the research on clinical reasoning that has been conducted over the last decades. This article synthesizes the findings of this research that help in particular to understand the cognitive processes involved in clinical reasoning, the trajectory that leads the student from novice to expert, and instructional approaches that have been shown to be useful to facilitating this trajectory. The focus of the article is the diagnostic process, because it is about it that most research has been conducted. This research indicates that there is not a particular reasoning strategy that is specific to expert physicians and could be taught to students. It is the availability of a large knowledge base organized in memory in illness scripts of different formats that explains the expert's better performance. The more, the richer, and the more well-structured are the illness scripts a physician has stored in memory, the more he/she would be able to make accurate diagnoses. These scripts are formed gradually over the years of education. To help develop them, students should be exposed to a wide variety of clinical problems, with which they must interact actively. Instructional approaches that require students to systematically reflect on problems, analyzing differences and similarities between them, explaining underlying mechanisms, comparing and contrasting alternative diagnoses, have proved useful to help refine disease scripts. These approaches are valuable tools for teachers concerned with the development of their students clinical reasoning.

Key words: clinical reasoning; medical expertise; diagnostic reasoning; clinical teaching.

Resumo: O raciocínio clínico é um fator determinante da performance do médico, crucial para chegar a um diagnóstico correto e possibilitar decisões terapêuticas adequadas. Ajudar seus estudantes a desenvolver o raciocinio clínico é um desafio diário de muitos professores e, para selecionar estratégias de ensino adequadas, pode ser útil conhecer um pouco dos resultados da pesquisa sobre raciocinio clínico que vem se desenvolvendo já há algumas décadas. Este artigo traz uma sintese de achados desta pesquisa que ajudam a compreender os processos cognitivos envolvidos no raciocínio clínico, a trajetória que leva o estudante de uma condição de "iniciante" 'a de "expert" e abordagens instrucionais que têm se mostrado úteis para facilitar esta trajetória. O foco do artigo é o processo diagnóstico, porque é ele que tem sido o objeto central de pesquisa. Esta pesquisa indica que não há estratégias de raciocínio especificas, próprias do médico expert, que possam ser ensinadas ao estudante. É a existência de uma larga base de conhecimentos organizados na memória em scripts de doenças de diversos formatos que explica o melhor desempenho do expert. Quanto mais numerosos, mais ricos e melhor organizados são os scripts que um médico tem na memória, mais apto ele está para fazer diagnósticos acurados. Estes scripts são formados gradualmente ao longo dos anos de formação e para desenvolvê-los o estudante deve ser exposto a uma grande diversidade de problemas clínicos, com os quais ele deve 
interagir de forma ativa. Abordagens instrucionais que requerem que o estudante reflita de forma sistemática sobre os problemas, analisando diferenças e similaridades entre eles, explicando mecanismos subjacentes, comparando e contrastando diagnósticos alternativos têm se mostrado úteis para ajudar a refinar scripts de doenças e são ferramentas valiosas para os professores interessados no desenvolvimento do raciocinio clínico de seus estudantes.

Palavras-chave: raciocinio clínico; competência médica; raciocínio diagnóstico; ensino clínico.

\section{Introduction}

The physician in an emergency department sees a 27-year-old patient with non-productive cough and pain in the right hemithorax that started 24 hours ago, worsens with inspiration and is associated with dyspnea. Instantly, the hypothesis of pneumonia comes to the physician's mind and leads him to question whether the patient had fever, cough, hemoptysis... Faced with the information that the patient was afebrile and had an episode of hemoptysis, the hypothesis of pulmonary embolism pops up in his mind and leads him to ask ....whether the patient uses oral contraceptives. Arriving at the diagnosis in a clinical encounter like this one involves a sequence of extremely complex cognitive processes. It requires distinguishing between information that is relevant in the situation and information that is not, generating possible explanations for the problem, deducing from these explanations which additional findings he should search for and, after obtaining them, evaluating their relationship with each of the explanations under consideration. Multiple competencies are certainly important to make the doctor successfully navigate through these processes, but accurate clinical reasoning is a crucial one. In their daily work in medical schools, many teachers are faced with the challenge of finding strategies to help their students develop their own reasoning. This article was written for these teachers, who can possibly benefit from an understanding of the cognitive processes involved in clinical reasoning, the trajectory through which the student develops from novice to expert, and the instructional approaches that have proved useful to facilitate this trajectory. The article synthesizes the available literature on these three issues. It focuses on key issues within this literature, without aiming at a comprehensive review or at describing methodological aspects of the research on these three issues. The cognitive processes involved in the diagnosis are the focus of the article, not because other dimensions - affective, for example - are irrelevant or because therapeutic decisions are less important. The cognition underlying the diagnosis is the focus, because it is on it that research on clinical reasoning has concentrated and generated most of its results.

\section{How clinical reasoning leads the doctor to the diagnosis}

The first research programs on clinical reasoning, in the 1970s, aimed to understand the reasoning process that an experienced doctor uses to solve problems, which could then be taught to the student [1]. From these programs emerged the idea that the 'hypothetical-deductive reasoning model' would characterize an expert doctor. At the beginning of the clinical encounter, the physician would generate diagnostic hypotheses and then obtain more information to confirm or refute these hypotheses [2]. However, difficulties emerged soon, when several studies showed that, in fact, from beginners to experienced doctors, everyone used more or less the same hypotheticaldeductive reasoning process [2,3]. The difference between experts and novices was simply that the experts generated better hypotheses. Rather than any peculiarity of the reasoning process, the accuracy of the initial hypothesis predicted the accuracy of the diagnosis [4]. Moreover, an expert's performance on one problem did not predict performance on another problem, even within the same specialty, a phenomenon that became known as 'content specificity' $[2,5,6]$.

These findings brought substantial evidence against the idea that experts used a particular type of reasoning process and that a general reasoning skill existed that would explain their best performance and could be taught to students. Research then turned to the content, that is, expert knowledge, moving to examine types of knowledge, how 
knowledge was organized in memory, activated and used in diagnostic reasoning [1].

Several theories exist about the cognitive structures that organize expert knowledge semantic networks, examples, prototypes, scripts - and indeed different forms of organization probably coexist in memory and are used depending on the circumstances [7]. The basic idea is that a mental representation of a disease knowledge associates that disease with a set of 'findings' ('findings' in a comprehensive sense). Briefly, what happens in the diagnostic process is that some findings of the problem activate in the physician's memory the knowledge of the disease to which they are associated, and a hypothesis is generated. This triggers a search, guided by the mental representation of the disease, for additional information to check if other findings associated with that disease are also present. When the search reveals findings that contradict the initial hypothesis, another hypothesis is generated, restarting the process.

In recent years, this basic model of clinical reasoning has gained support from research in psychology. This research has generated substantial empirical evidence for the existence of two different forms of reasoning, one that is based on pattern recognition, fast, automatic and largely intuitive, and another that depends on the application of rules, is slow, demands effort and is subject to conscious control [8-10]. The literature usually refers two these to reasoning modes as Type 1 (or System 1) and Type 2 (or System 2). They apparently apply well to the diagnostic process, with Type 1 involved in hypothesis generation and Type 2 in its verification. While some authors associate cognitive biases (and consequent diagnostic errors) with failures of Type 1 mode [11,12], others argue that such errors do not derive from a particular reasoning process but from specific gaps in knowledge about the disease at hand [13]. This debate is beyond the scope of this article, but recent reviews are available for those interested on it [14,15].

Note that the idea from the beginning of research on clinical reasoning of a hypothetical-deductive diagnostic reasoning process remains. However, it is now recognized that this is not a reasoning process independent of content, but rather a strategy to access and use knowledge organized in representations of diseases stored in memory $[1,16]$. A view of how these structures evolve over the years of medical training can possibly help teachers facilitate their development among their students.

\section{The development of clinical reasoning: the trajectory from novice to expert}

One of the most influential theories on the development of clinical reasoning throughout education assumes that such development implies more than expansion of the knowledge base by acquiring new concepts and better connections between them. It also involves knowledge restructuring, with evolving stages characterized by different forms of knowledge organization in memory and use in the diagnosis observed throughout education [17,18]. In the initial years, the student quickly forms causal networks in memory, linking clinical findings to the pathophysiological processes that produced them. At this stage, students still do not yet recognize patterns of findings that usually come together and, when solving clinical cases, explain isolated findings based on pathophysiological processes [19].

As this knowledge is used to understand clinical problems, it is gradually 'encapsulated' in more generic explanatory models that group together different concepts and their relationships $[17,20]$. For example, when required to explain the findings of a drug-addicted patient who developed sepsis students go step-by-step through the entire chain of events from the use of contaminated syringes to the clinical manifestations. An expert, on the other hand, uses the concept of 'sepsis' as an explanatory model that 'encapsulates' many of the intermediate processes, eliminating the need to use the knowledge of these processes in diagnostic reasoning.

Practice with patients induces a second change in the way knowledge is organized, with the development of 'illness scripts' [17,21,22]. Scripts are cognitive structures that 'represent' a 
patient with that disease, containing knowledge of the conditions that make the disease more or less likely, the clinical manifestations of the disease, and its pathophysiological processes, the latter more succinct because of encapsulation. There are scripts of different levels of specificity, representing disease prototypes, diagnostic categories, or even traces in the memory of real patients previously seen [17,23].

Illness scripts play a crucial role in the diagnostic process. In the first moments of a clinical encounter, patient characteristics activate an illness script in the doctor's memory, and a diagnostic hypothesis is generated. The script then guides the search for more information, with the doctor basically checking whether the patient's findings match the elements of the script $[17,21]$. As experience with patients with a certain disease grows, the physician tends to incorporate into his/her script not only the findings of the typical presentation of the disease, but also the atypical formats, which makes him/her able to recognize the disease even when it does not present as it appears in the textbooks. The more illness scripts the doctor has stored in memory and the richer and better structured the scripts are, the more well prepared he/she would be for the diagnostic process. Fostering the development of a large base of illness scripts is therefore crucial to help students develop clinical reasoning [16-18].

\section{The teaching of clinical reasoning}

From all these years of research on clinical reasoning, one conclusion seems clear. Because there is neither a generic reasoning skill that is carried from one problem to another nor an expert's specific reasoning mode, it makes no sense to intend to teach the student 'how to reason' $[16,24]$. Since it is an extensive knowledge base that determines diagnostic performance, the primary task is to help students develop such base.

Although this conclusion is widely supported by empirical evidence, it is not always reflected in the literature on the teaching of clinical reasoning. A recent review has shown that descriptions of curricula/courses that are intended to teach decision-making theory and/or a specific reasoning strategy are still common [24]. The literature on diagnostic error also often presents proposals for interventions that aim to reduce susceptibility to cognitive biases by teaching reasoning strategies to counteract them. The few studies that have evaluated the effects of such educational interventions on actual diagnostic performance indicate minimal impact or none[25,26]. In contrast, strategies aimed at increasing specific knowledge, for example of critical findings that help distinguish between similar-looking diseases, seem promising to 'immunize' against bias in reasoning [27].

Knowing that there seems to be no way to teach 'how to reason' may look disappointing to teachers. However, recent investigations have opened up a new - and apparently promising - perspective for the teaching of clinical reasoning. From these investigations, principles emerged that can guide the design of educational interventions to help develop a broad, diverse base of mental representations of diseases. Some of these principles that seem most important are outlined below.

First, providing students with appropriate experience with clinical problems appears as an essential element for teaching clinical reasoning $[1,16,24]$. There seems to be nothing new here, because experience with patients or case reviews for example has always been highly valued in medical education. However, in order to facilitate the development of illness scripts, students must be exposed not to a few very elaborate or complex cases, but to a great diversity of examples of a wide variety of diseases, in a diversity of clinical presentations. And it is not that any examples will do. The cases should be at the appropriate level. On the one hand, students need to have enough knowledge to engage with the cases. On the other hand, the cases must be challenging, demand effort, reach the limits of the students' competence [6,16,24].

A second important issue is what is actually the practice with clinical problems. Studies from various fields [28-31] have shown that what students can learn from practice with problems depends on what they are requested to do with them [24]. 
The student needs to actively engage in problem solving and actively process its information. There are substantial advantages in using instructional approaches that lead the student to compare similarities and differences between problems, identifying for example structural differences that explain why two problems that appear superficially similar are in fact different (or viceversa). The purpose of the practice should be to increase both the knowledge of the clinical findings associated with a given disease and the knowledge of the pathophysiological mechanisms underlying these findings. The latter seems to 'glue' together apparently disconnected signs and symptoms, increasing the coherence of the mental representation of the disease and facilitating its recognition in the future [32].

To make this exercise of reflecting upon problems possible, a third issue must be considered. Practice with problems should be organized in such way that allows for comparing and contrasting cases of different diseases that share a similar clinical presentation. This 'mixed practice' format would group together in the same exercise, for example, cases like the one that opened this article and cases of other diseases that would be alternative diagnoses for patients with that clinical presentation. This would allow the student to compare the clinical findings encountered in the problems, contrasting them with those expected from the various alternative diagnoses. Comparing/contrasting examples apparently helps to develop mental representations of problems [33.34], but this becomes difficult when practice with problems occurs in 'block', that is, grouping together several examples of the same disease.

Instructional approaches based on these principles have shown to be effective in many experimental studies over the past few years. For example, 'self-explanation', a learning strategy originally studied in other areas, requires students to diagnose clinical cases by explaining to themselves the pathophysiological mechanisms underlying those manifestations [35]. In several studies, students who used self-explanation during practice with problems made more correct diagnoses when they encountered similar cases in the future than students who had used more conventional approaches, such as making differential diagnosis [36-38]. Another strategy, 'deliberate reflection', makes it possible to compare and contrast clinical cases by following a systematic procedure. Deliberate reflection has been shown, in several experimental studies, to be more effective in developing diagnostic competence than more conventional approaches [39-41].

At this point, a teacher may be wondering how this evidence generated by research could be incorporated into teaching practice. In many schools, the teaching of clinical reasoning is still based on the assumption that the ability to reason clinically is acquired 'naturally' when students begin to apply the previously acquired knowledge to address patients' problems, observing the teacher as a model. This tradition is changing, perhaps due to the recognition of the limitations of real practice environments for teaching clinical reasoning [24]. In these environments, supervision and feedback are limited, and there is no way to guarantee experience with a wide variety of problems $[42,43]$. Experience with real patients has a key role in physicians' education and remains crucial to develop several dimensions of professional competence. However, the teaching of clinical reasoning cannot depend solely on the experience with real patients. Many medical schools have therefore created specific programs for teaching clinical reasoning, sometimes starting already in the first years, to ensure that students are provided with an extensive practice with appropriate supervision and feedback [24]. The essential learning resource in these programs consists of clinical cases. There are a wide variety of formats, with programs using written or video cases, others featuring simulated patients, real patients, or even virtual patients, and exercises with cases occurring individually or in groups, in classrooms or clinical settings, face-to-face or online. There is therefore much room for the teacher's creativity, especially because a program of exercises with clinical cases does not necessarily 
require special resources. Research has shown that the fidelity of simulations, which usually demands more developed technology, does not seem to substantially influence learning [44,45]. Much more crucial seems to be to align the practice with problems with the principles that research over the last decades has shown to be valid.

In summary, research on clinical reasoning in recent decades indicates that there are not reasoning strategies that are specific to the expert physician that could be taught to students. What explains the expert better performance is a large knowledge base organized in memory in illness scripts of different formats. These mental representations of diseases are gradually formed during education and, in order to develop them, students must be exposed to a large diversity of clinical problems. Instructional approaches that require reflecting on problems, analyzing their differences and similarities, explaining mechanisms underlying clinical manifestations, comparing and contrasting alternative diagnoses, have proven useful to refine mental representations of diseases and are important tools for teachers interested in developing their students clinical reasoning.

\section{Notes:}

\section{Funding}

This study did not receive financial support from external sources

\section{Conflicts of interest disclosure}

The authors declare no competing interests relevant to the content of this study.

\section{Availability of data and responsibility for the results}

The author declares to have had full access to the available data and they assume full responsibility for the integrity of these results.

\section{REFERENCES}

1. Norman G. Research in clinical reasoning: past history and current trends. Med Educ. 2005:39(4):418-27. https:// doi.org/10.1111/j.1365-2929.2005.02127.X.
2. Elstein AS. Medical Problem Solving: An Analysis of Clinical Reasoning. Cambridge, MA/London, U.K.: Harvard University Press; 1978.

3. Neufeld VR, Norman GR, Feightner JW, et al. Clinical problem-solving by medical students: a cross-sectional and longitudinal analysis. Med Educ. 1981;15(5):315-22. https://doi.org/10.1111/j.1365-2923.1981.tb024.95.x.

4. Barrows HS, Norman GR, Neufeld VR, et al. The clinical reasoning of randomly selected physicians in general medical practice. Clin Invest Med. 1982;5(1):49-55.

5. Eva KW. On the generality of specificity. Med Educ. 2003:37(7):587-8. https://doi.org/10.1046/j. 1365-2923.2003.01563.x.

6. Eva KW, Neville AJ, Norman GR. Exploring the etiology of content specificity: factors influencing analogic transfer and problem solving. Acad Med. 1998;73(10 Suppl):S1-5. https://doi.org/10.1097/00001888199810000-00028.

7. Custers EJ, Regehr G, Norman GR. Mental representations of medical diagnostic knowledge: a review. Acad Med. 1996:71(10 Suppl):S55-61. https://doi. org/10.1097/00001888-199610000-00044.

8. Evans JSBT. Dual-processing accounts of reasoning, judgment, and social cognition. Annu Rev Psychol. 2008:59:255-78. https://doi.org/10.1146/annurev.psych.59.103006.093629.

9. Evans JST. The heuristic-analytic theory of reasoning: Extension and evaluation. Psychon B Rev. 2006;13(3):378-95. https://doi.org/10.3758/BF03193858.

10. Kahneman D. A Perspective on Judgment and Choice: Mapping Bounded Rationality. Am Psychol. 2003:58(9):697-720. https://doi.org/10.1037/ 0003-066X.58.9.697.

11. Croskerry P. The importance of cognitive errors in diagnosis and strategies to minimize them. Acad Med. 2003:78(8):775-80. https://doi.org/10.1097/00001888200308000-00003.

12. Croskerry P. Cognitive forcing strategies in clinical decisionmaking. Ann Emerg Med. 2003:41(1):110-20. https://doi.org/10.1067/mem.2003.22.

13. Norman G. Dual processing and diagnostic errors. Adv Health Sci Educ Theory Pract. 2009;14 Suppl 1:3749. https://doi.org/10.1007/s10459-009-9179-X.

14. Lambe KA, O'Reilly G, Kelly BD, et al. Dual-process cognitive interventions to enhance diagnostic reasoning: a systematic review. BMJ Qual Saf. 2016. https:// doi.org/10.1136/bmjas-2015-004417.

15. Norman GR, Monteiro SD, Sherbino J, et al. The Causes of Errors in Clinical Reasoning: Cognitive Biases, Knowledge Deficits, and Dual Process Thinking. Acad Med. 2017:92(1):23-30. https://doi.org/10.1097/ ACM.0000000000001421. 
16. Eva KW. What every teacher needs to know about clinical reasoning. Med Educ. 2005:39(1):98-106. https:// doi.org/10.1111/j.1365-2929.2004.01972.x.

17. Schmidt HG, Rikers RM. How expertise develops in medicine: knowledge encapsulation and illness script formation. Med Educ. 2007;41(12):1133-9.

18. Schmidt HG, Norman GR, Boshuizen HPA. A Cognitive Perspective on Medical Expertise - Theory and Implications. Acad Med. 1990;65(10):611-21. https://doi. org/10.1097/00001888-199010000-00001.

19. Schmidt HG, Boshuizen HPA. On the Origin of Intermediate Effects in Clinical Case Recall. Mem Cognit. 1993;21(3):338-51. https://doi.org/10.3758/BF03208266.

20. Rikers RMJP, Schmidt HG, Boshuizen HPA. Knowledge encapsulation and the intermediate effect. Contemp Educ Psychol. 2000;25(2):150-66. https://doi. org/10.1006/ceps.1998.1000.

21. Charlin B, Boshuizen HPA, Custers EJ, et al. Scripts and clinical reasoning. Med Educ. 2007:41(12):1178-84. https://doi.org/10.1111/j.1365-2923.2007.02924.X.

22. Schmidt HG, Boshuizen HPA. On Acquiring Expertise in Medicine. Educ Psychol Rev. 1993:5(3):205-21. https:// doi.org/10.1007/BF01323044.

23. Hobus PPM, Schmidt HG. Boshuizen HPA, et al. Contextual Factors in the Activation of 1st Diagnostic Hypotheses - Expert Novice Differences. Med Educ. 1987;21(6):471-6. https://doi.org/10.1111/j.1365-2923.1987.tb01405.X.

24. Schmidt HG, Mamede S. How to improve the teaching of clinical reasoning: a narrative review and a proposal. Med Educ. 2015:49(10):961-73. https://doi. org/10.1111/medu.12775.

25. Sherbino J, Dore KL, Wood TJ, et al. The relationship between response time and diagnostic accuracy. Acad Med. 2012;87(6):785-91. https://doi.org/10.1097/ ACM.0b013e318253acbd.

26. Sherbino J, Kulasegaram K, Howey E, et al. Ineffectiveness of cognitive forcing strategies to reduce biases in diagnostic reasoning: a controlled trial. CJEM. 2014:16(1):34-40. https://doi. org/10.2310/8000.2013.130860.

27. Mamede S, de Carvalho-Filho MA, de Faria RMD, et al. 'Immunising' physicians against availability bias in diagnostic reasoning: a randomised controlled experiment. BMJ Qual Saf. 2020. https://doi.org/10.1136/ bmjis-2019-010079.

28. Loewenstein J, Thompson L, Gentner D. Analogical Learning in Negotiation Teams: Comparing Cases Promotes Learning and Transfer. Acad Manag Learn Edu. 2003:2(2):119-27. https://doi.org/10.5465/ amle.2003.9901663.
29. Gentner D, Loewenstein J, Thompson L. Learning and transfer: A general role for analogical encoding. J Educ Psychol. 2003:95(2):393-408. https://doi. org/10.1037/0022-0663.95.2.393.

30. Ericsson KA. Acquisition and Maintenance of Medical Expertise: A Perspective From the Expert-Performance Approach With Deliberate Practice. Acad Med. 2015;90(11):1471-86. https://doi.org/10.1097/ ACM.0000000000000939.

31. Ericsson KA, Krampe RT, Teschromer C. The Role of Deliberate Practice in the Acquisition of Expert Performance. Psychol Rev. 1993;100(3):363-406. https://doi. org/10.1037/0033-295X.100.3.363.

32. Woods NN, Brooks LR, Norman GR. It all make sense: biomedical knowledge, causal connections and memory in the novice diagnostician. Adv Health Sci Educ Theory Pract. 2007:12(4):405-15. https://doi. org/10.1007/s10459-006-9055-X.

33. Ark TK, Brooks LR, Eva KW. The benefits of flexibility: the pedagogical value of instructions to adopt multifaceted diagnostic reasoning strategies. Med Educ. 2007:41(3):281-7. https://doi.org/10.1111/i. 1365-2929.2007.02688.x.

34. Hatala RM, Brooks LR, Norman GR. Practice makes perfect: the critical role of mixed practice in the acquisition of ECG interpretation skills. Adv Health Sci Educ Theory Pract. 2003;8(1):17-26. https://doi.org/10.1023/A:1022687404380.

35. Chamberland M, Mamede S. Self-Explanation, An Instructional Strategy to Foster Clinical Reasoning in Medical Students. Health Professions Education. 2015;1(1):24-33. https://doi.org/10.1016/j.hpe.2015.11.005.

36. Chamberland M, Mamede S, St-Onge C, et al. Self-explanation in learning clinical reasoning: the added value of examples and prompts. Med Educ. 2015;49(2):193-202. https://doi.org/10.1111/medu.12623.

37. Chamberland M, Setrakian J, St-Onge C, et al. Does providing the correct diagnosis as feedback after self-explanation improve medical students diagnostic performance? BMC Med Educ. 2019;19(1):194. https:// doi.org/10.1186/s12909-019-1638-3.

38. Chamberland M, St-Onge C, Setrakian J, et al. The influence of medical students' self-explanations on diagnostic performance. Med Educ. 2011;45(7):688-95. https://doi.org/10.1111/j.1365-2923.2011.03933.x.

39. Mamede S, Figueiredo-Soares T, Eloi Santos SM, et al. Fostering novice students' diagnostic ability: the value of guiding deliberate reflection. Med Educ. 2019:53(6):628-37. https://doi.org/10.1111/medu.13829.

40. Mamede S, van Gog T, Moura AS, et al. Reflection as a strategy to foster medical students' acquisition of diagnostic competence. Med Educ. 2012;46(5):464-72. https://doi.org/10.1111/j.1365-2923.2012.04217.x. 
41. Mamede S, van Gog T, Sampaio AM, et al. How can students' diagnostic competence benefit most from practice with clinical cases? The effects of structured reflection on future diagnosis of the same and novel diseases. Acad Med. 2014;89(1):121-7. https://doi. org/10.1097/ACM.0000000000000076.

42. Rattner SL, Louis DZ, Rabinowitz C, et al. Documenting and comparing medical students' clinical experiences. JAMA. 2001;286(9):1035-40. https://doi. org/10.1001/jama.286.9.1035.

43. Wimmers PF, Schmidt HG, Splinter TA. Influence of clerkship experiences on clinical competence. Med Educ. 2006;40(5):450-8. https://doi.org/10.1111/ j.1365-2929.2006.02447.X.

44. de Giovanni D, Roberts T, Norman G. Relative effectiveness of high- versus low-fidelity simulation in learning heart sounds. Med Educ. 2009:43(7):661-8. https://doi.org/10.1111/j.1365-2923.2009.03398.x.

45. Massoth C, Roder H, Ohlenburg H, et al. High-fidelity is not superior to low-fidelity simulation but leads to overconfidence in medical students. BMC Med Educ. 2019:19(1):29. https://doi.org/10.1186/s12909-019-1464-7.

\section{Silvia Mamede}

PhD in Medical Education from the Erasmus University Rotterdam; associate professor, Institute of Medical Education Research Rotterdam, Erasmus Medical Center, and Erasmus School of Social and Behavioral Sciences, Erasmus University Rotterdam, The Netherlands.

\section{Mailing Address:}

Silvia Mamede

Institute of Medical Education Research Rotterdam, Erasmus MC, University Medical Centre Rotterdam, Erasmus Medical Centre

Ae-242, Wytemaweg 80, 3015 CN

Rotterdam, The Netherlands. 